\title{
Translation as Accommodation: Influences of Contextual Factors on a Translator
}

\author{
Aamir Majeed $^{1} \&$ Fauzia Janjua $^{2}$ \\ ${ }^{1} \mathrm{PhD}$ Scholar, Department of English, National University of Modern Languages, Islamabad, Pakistan \\ ${ }^{2}$ Associate Professor, Department of English, International Islamic University, Islamabad, Pakistan \\ Correspondence: Aamir Majeed National University of Modern Languages Islamabad, Pakistan. E-mail: \\ aamirmajeed49@gmail.com
}

$\begin{array}{ll}\text { Received: November 10, } 2018 & \text { Accepted: December 21, 2018 Online Published: January 29, } 2019 \\ \text { doi:10.5539/ijel.v9n2p42 } & \text { URL: https://doi.org/10.5539/ijel.v9n2p42 }\end{array}$

\begin{abstract}
The present study attempts to investigate how contextual factors with ideology as the major component affect the process of translation and influence translators to adopt accommodations in translated text because all translations are ideological in one way or the other because preference of definite terms is motivated by the aims and interests of target society. For this purpose the researcher selected short story 'Overcoat' written by renowned Pakistani writer Ghulam Abbas and its English version included in syllabus of intermediate class. The author is a professional Urdu writer whose text is translated by PTB Lahore for academic purpose. The translated text was analyzed and compared and contrasted with the original text to trace the accommodation patterns which are adjustments to adjust target text in new context. The source context is informal, free and wide with a variety of readerships whereas target context is formal, restricted and with a specific type of readerships. Analytical framework is a fusion of Van Dijk (2005) approach of text analysis and Shi's (2004) model of translation as accommodation. The analytical framework demonstrates that the analysis of the texts starts individually and then after analyzing macro and micro structures of the texts comparatively, draws the conclusion. The findings show that there are significant ideological and cultural accommodations in the target text.
\end{abstract}

Keywords: ideological factors, accommodation, contextual factors, macro and micro structures

\section{Introduction}

\subsection{Statement of the Problem}

Language necessitates a systematic operation and combination of different factors to become meaningful. Each speech act needs a unique socio-political and cultural background to become consequential. Along with these contextual factors, many linguistic features and participants of the speech act also spin the meaning of linguistic presentation. Language is performed in a culture as Sapir (1921) states that language exists inside its culture and it is socially acquired set of practices and beliefs that establishes the structure of our lives. So change in any of these contextual factors changes the meanings of linguistic performance. In order to preserve its meanings and effects in new context or change in participants, language needs to be changed.

\subsection{Importance of the Research Problem}

Hatim \& Mason (1997) assert that the pragmatic features of a language provide evidence on the basis of which meanings are constructed. In the case of written discourse the situation becomes more diverse because all written discourses travel across a range of contexts through a variety of readerships. At each stage it is construed differently because of the difference in contextual factors. In case of translation, the situation becomes more complex because translation is meant for different readerships and surely to be used in different ideological context that includes religious beliefs, socio-cultural norms and political way of thinking. On the other hand faithfulness in translation demands that a translator should be faithful to the original meanings of text (Pal, 2004:21). So a translator needs to negotiate between the faithfulness and target contextual features of translated text. Nord (2001) proposes two types of translation i.e. documentary vs. instrumental translations. These help to understand the situation. In the former translators aim to protect the source text setting while in the later they try to adopt context settings in other words adopt adaptations/accommodations. Translation is meant for target context and readers, so it must adhere to the target readers and context. On the other hand if we record the source 
text (ST) written in source language (SL) into target text (TT) written in target language (TL), we may not suppose to create the same effects (meanings). In other words mere transcription of the message in target language will not exert the same impact as might have been supposed by the source author. Here certainly the translator needs to make necessary adjustments to adjust the text in new context. These adjustments are adaptations or accommodations that are the issue to be investigated in this research. Shi (2004) believes that in spite of the so much value on faithfulness by translation theorists, a closer look makes it clear that accommodation or adaptation is a general feature in all available translations. This accommodation may be according to the collocation patterns or aesthetic norms of the target language or in adherence with the cultural and ideological values of the target readers' context. Religion plays a pivotal role not only in social and cultural spheres of human activity but also in choice of language. So, ideological factors may likely to affect all other factors causing accommodation in translation. Short story 'Overcoat" written by Ghulam Abbas and its English version that is the part of the short stories included in intermediate syllabus, is taken as corpus of this research.

\subsection{What Is Translation?}

Translation means the transfer of message of source text into the target text. The purpose of translation is to make a variety of the texts available for a wider range of readerships. But it must be kept in mind that languages are not merely the nomenclature but based on nexus of ideologies, culture and power dynamics of that society. The more different are these factors, more problematic process of translation will be. Translation process undergoes following stages.

\subsubsection{Translation Procedure}

Translation procedure is the preliminary measures to start translation of a text. This procedure works as under;

(a) Analysis of the both source text and target text

(b) A thorough study of source text before starting empirical work

(c) Judging the semantic and syntactic approximation

\subsubsection{Translation Strategies}

Translation strategies are the basic tasks of choosing a text for translation and developing a method or technique to translate it. A strategy is basically an analysis, selection and adoption of the method/technique which a translator adopts while translating a text. These can be syntactic, semantic and pragmatic.

\subsubsection{Translation Methods}

Method or technique is an empirical attempt to translate a text. Translation can be attempted differently according to the nature and demand of the text. There can be different methods or techniques of translation. Literal translation, word for word translation, faithful translation, free translation and accommodation are some the main methods of translating a text. Each of these methods of translation may have some textual or contextual implications. Accommodation or adaptation is one of the methods/techniques of translation that emerged with the emergence of critical trends in translation.

\subsubsection{What Is Accommodation?}

Adaptation in translation means changes introduced in line with the spirit of the original text. As a result a text is produced which is not a translation in ordinary sense; it is rather a piece of writing that manages to communicate more of what was intended by the original author. Accommodation is a synonym to adaptation which means an adaptation of a text to broader target cultural and linguistic norms to make it easy for readers to understand, to make it natural in the target language and to preserve the source message essence, impact, and effect. Ibraheem (2013) concludes his discussion by stating that accommodation is probably borrowed from Communication Accommodation Theory, and it deals with the process by which people change their language behaviour according to the context of target language users. He further asserts that accommodation, adaptation or domestication refer to the target-context-oriented translation in which atypical expressions to the target culture are exploited and turned into some recognizable ones so as to make the translated text comprehensible and easy for the target readers. Accommodation is also translation, whether it is an addition or loss of information, explanation, rewriting, or re-creation. It must, more often than not, be adopted to avoid the risk of loss of meaning or creating a clash of understanding. Zirker (2016) opines that the translation of character-specific language seems to be impossible because either the character is no longer recognizable as linguistically distinct or the wordplay is lost, unintelligible or no longer witty or both character and wordplay are lost in translation. This is particularly problematic as it hinders the course of translatability. While the translatability of wordplay in general is certainly not impossibility as it makes room for the translator to reorganize the content being translated. 
This leads him/her to adopt the structures and features of target language to convey the message of source language. Eventually, wordplay and contextual features of source text affect communication in translation. This effect results in the form of omission, addition, rewriting or explanation which is none the less accommodation or adaptation or adjustment.

Jost, Glaser, Kruglanski, \& Sulloway (2003) believe that language is a discursive practice which means it is socially constructed and based on particular structures and a function (objective). These structures and function refer to the network of ideologies and contextually constructed attitudes and norms. Language as a discursive practice becomes meaningful if it is adjusted in the very context of its use. If linguistic practice is not adjusted in its context according to the context of its use, it is likely to become meaningless. In short the adjustments according to the ideologies of the target readers and linguistic features of target language are called accommodations

\subsubsection{Accommodation in Translation}

In modern world there is a decisive role of a translator in the field of translation. Many odd jobs that were not included in the sphere of translation theories and practice like adaptation, localization, subtitling and dubbing are now in some contexts and under certain conditions considered as an integral part of a translator's jobs .Therefore, to investigate various forms of accommodation which a translator aim at while translating a text. Some of these types of accommodation are purely technical like the translation of advertisements or websites, aesthetic or stylistic like translation of poetry or even ideological like translation of political discourse. Gone is the time of faithfulness in translation, now is the era of mediation and diplomacy. It looks quite natural for a translator to play a role a mediator or even a negotiator rather than that of a pure translator or a compiler of a bilingual dictionary in a globalization era. Translation is not simply a linguistic renovation or transformation between languages but it involves accommodation in scope of ideology, culture, aesthetics, and many other factors. The discussion about translation as a process or as a product gives way to the discovery that translation includes so many perspectives: the linguistic, the semiotic, the cultural, the social and the psychological as regards communication. In fact, translation offers a broader concept of what it means to understand and to be understood. Moreover, it is inevitable in practice if the translation is to maintain the source message essence, impact, and effect. Faithfulness was once considered the iron rule in translation, yet when we take a closer look, accommodation, or adaptation, is found in most published translations. Accommodation is also translation, even though it means addition or loss of meanings, or explanation or rewriting, or re-creation. Accommodation must, more often than not, be adopted. Accommodation as a translation technique was considered the exception or an altogether different activity than the older concept of translation that was very close to transcribing the message.

Yanow (2004) asserts that translation is not just a linguistic transformation of lexical or syntactical equivalences of two languages rather it is the adjustment of the message of a text in a new context in order to achieve definite objectives. The advocates of communicative functional approach to translation Sdobnikov (2011) believe that translation is done not in a vacuum but in an ideology-filled environment that influences the process of translation. Schäffner (2004) opines that all texts include ideological beliefs which are associated to a particular group of people. When such text is translated for different readers, it needs to reflect on the ideologies of target readers. Moreover linguistic aspects of target language also play significant role in the adjustment of target context. This consideration of target readers' ideologies and structural patterns of target language ultimately leads translator to adapt that translated text according to the new context. So a translator needs to take necessary actions in order to adjust a target text in target context. This adjustment of a translated text according to the new context is called accommodation in translation. This contextual adaptation involves accommodation according to ideology, culture, and syntactic structure and aesthetic values of the language. Shi (2004) introduce four types of accommodations i.e. ideological accommodation, cultural accommodation, aesthetic accommodation and collocation accommodation. These adjustments are caused by ideological, cultural, aesthetic and linguistic factors. In simple words these four types of contextual accommodation can be categorized into two categories i.e. one caused by abstract factors that are belief system of the target society and concrete factors consist of the linguistic features of that language.

\subsection{Objective of the Study}

The present study attempts to achieve the following objective.

To explore the ways, methods and styles of accommodations which the translator has adopted while translating 'Overcoat' 


\subsection{Research Question of the Study}

In order to find out the ways and reasons of translator's accommodation in Pakistani social context, the present study will revolve around the following research question.

\section{$>$ How has the translator of "Overcoat" accommodated while translating it from Urdu to English?}

\subsection{Target Readers of the Selected Texts}

The target readers of the original text are the common Pakistanis who take interest in literature whereas target readers of translated version are the students of intermediate level. Original discourse is translated by Punjab Textbook Board Lahore for academic purpose.

\section{Methodology}

The current study is basically qualitative in nature however quantification of some of the imperative aspects of the findings makes it an incorporated form of inquiry. Mixed method of data analysis according to Johnson \& Onwuegbuzie (2004) authorizes the use of eclectic approach in obtaining the objectives of research and also finding answer to questions. It also dispirits the inclination to inflict restraints on researchers to choose either of the methods of analysis. Descriptive method of research has been applied to study the data both qualitatively and quantitatively. (Creswell, 2007) asserts that descriptive method in qualitative research includes description, explanation, and interpretation of the collected data whereas, Creswell (2007) states that descriptive method in quantitative research in text analysis helps a researcher to quantify and examine the occurrence, connotations and relationships of linguistic structures. Statistical procedures have been restricted to the calculation of percentages in order to validate the descriptions regarding analytical categories figured out by the implied framework of analysis.

\subsection{Analytical Framework of the Study}

The present study attempts to explore translation strategies that help translators to adapt target texts in new context. Contextual factors need to be traced in order to precede the discussion to achieve the objectives of the study. Lefevere (1992) has argued that translation is the rewriting of source text that is influenced by ideology, politics, sponsoring agency and context of discourse. He further states that out of these operating factors, ideological belief system of the target readers is the most important factor. Toury (2000) affirms that although it is generally believed that translators should be objective and faithful and all the prevailing perception is that the ideological inclinations of translators do not subsist in target texts, yet it is a determined fact that the ideology and cultural inclinations of translators are incorporated in every word they select, and during the entire process of translation. Similarly Nord (2006) argues that almost all steps in translation process are influenced by the context of target readers or translators, consciously or unconsciously. He believes that contextual factors play a significant role in the process of translation and at all steps and decisions in this regard. These arguments incite analysts of translation to apply CDA for the analysis of translation. Simon (2005) opines that the traces of ideology and political dynamics on the process of translation have been highlighted by the analysts. In some cases, the influences are quite explicit and obvious whereas in some other cases obscure and implicit influences can be traced after systematic and careful analysis. Simon (2005) also believes that there is an ever-increasing perception among translation scholars that process of translation and interpretation of text is context dependent and it is not simply language based activity. The ideologies and power dynamics imbedded in a text can be traced and interpreted with the help of Critical Discourse Analysis (CDA). O'Halloran, Tan, Smith, \& Podlasov (2010) states, the focus of CDA is the idea that ideological cues can be found in spoken and written texts. The presence of ideology in a text and traces of ideological manipulations have been the core areas of the focus of critical discourse analysts. For this purpose different strategies that have been employed by translators have been analyzed by discourse analysts to highlight ideological manipulations in target text. Baker (2006) proposes that it should also be the duty of the translators and interpreters to be faithful to the ideological norms and values of the society they represent. These ideas clearly report the significance of the role of ideological manipulations in the process of translation. In this regard, it is the role of CDA to point out the implicit agendas behind translation, to explicate the agency of translation and expectations of the target readers that may sway the process of translation. Munday (2008) believes that contextual factors which he labels as macro factors have gained primary position in translation studies whereas linguistic factors which he considers micro factors though equally important yet hold secondary position. He (ibid) counts macro factors as a translator's position, historical background, socio-cultural values, political norms and agendas of translators' funding agency which can be called ideological factors collectively. Afzali (2013) argues that the ideological presence of a translator in a translation has been traced noticeably by CDA analysts. In some cases, such ideological presence is clear and explicit whereas in some situations the presence is implicit and imbedded and it is the job of CDA to expose these implicit and 
imbedded ideologies in a text. (Afzali, 2013) concludes that the focus of CDA is to find ideological cues in spoken and written texts. Van Dijk (2005) model of critical discourse analysis provides useful insights for the critical analysis of written text.

\subsubsection{Van Dijk's Model of Text Analysis}

According to Van Dijk (2005) CDA as one of the main branches of Discourse Analysis has mainly focused on the links among different approaches to talking and thinking. Van Dijk (2005) analytical model for text analysis focuses on both macro structure (rhetoric, cohesion and coherent) and micro structure (syntax, vocabulary and diction) of a text. Among the constituents of CDA proposed by Van Dijk, lexicalization refers to the choice of words; passivation refers to changing the voice of sentence; modality shows the possibility of the happening of an action; omission refers to the exclusion of a word or group of words and addition refers to the inclusion of word/words without damaging the syntax of a sentence. The techniques proposed by Van Dijk, fall in syntactic, semantic or pragmatic strategies that cover both macro and micro structures of text during analysis. Syntactic strategies refer to the study of grammatical rules that govern the structure of a language. Semantic strategies refer to the choice of one word rather than another and the pragmatic strategies include plans and objectives of production of text that involve the intention of producers. To analyze the target text, primarily the text was explored to mark syntactic aspects such as grammatical selection and then grammatical selections were analyzed to see if they represented any ideological and contextual significance. Moreover the contents of the target text were analyzed with respect to the semantic features to probe to which extent these elements were ideologically-loaded and context-specific. Finally, the pragmatic features of the target text were explored to trace the intention and objective of the translator. Van Dijk (2005) model of critical discourse analysis is shown in the below given figure that explains in detail the steps of text analysis. This model helps to analyze the selected texts individually both at macro and micro levels.

\subsubsection{Shi's Model of Accommodation in Translation}

Shi's (2004) model for an analysis of accommodation in translation shows that the process of translation of source text is affected by abstract and concrete factors that are further divided into cultural values and ideological norms and linguistic structures and aesthetic trends and these sub categories result in cultural accommodation, ideological accommodation, collocation accommodation and aesthetic accommodation respectively. A translator adopts adaptation/accommodation at the above mentioned four levels with the help of different techniques of translation. These techniques help a translator to adjust both micro and macro structures of a source text into the structures of a target text according to the demands of target culture, ideology, linguistic structures and aesthetic trends of target context. A text affected by abstract and concrete factors goes through the process of accommodation and result in the form of target text.

Van Dijk (2005) model of text analysis and Shi's (2004) model of accommodations in translation combine to guide us devise an analytical framework for the present study. This analytical framework is a designed tool of analysis which consists of synthesis of the two analytical approaches selected for the study.

\subsubsection{Graphic Chart of the Analytical Framework}

The figure below shows in detail the analytical procedure and framework of the present study. This analytical framework is a fusion of Van Dijk (2005) approach of text analysis and Shi's (2004) model of translation as accommodation. The analytical framework demonstrates that the analysis of the texts starts individually and goes through the macro and micro structures of the texts. After analyzing both the texts individually, a comparative analysis of the selected texts is improvised both at macro and micro levels. After comparing strategies employed in the source text and target text, the next stage detects the techniques of translation that lead towards and help to trace the patterns of accommodation in translation at both macro and micro levels. These accommodation patterns are further classified into cultural, ideological, aesthetic and collocation accommodations in translation and are found both at macro and micro levels of the texts except collocation accommodation. Collocation is a linguistic feature that occurs only at phrase level. So collocation at macro level is not possible as macro level analysis is an analysis above the level of sentence; hence no need to discuss collocation accommodation at macro level in the upcoming sections. This analytical framework provides a route for the analysis of the data and formulation of the results in the upcoming sections. 


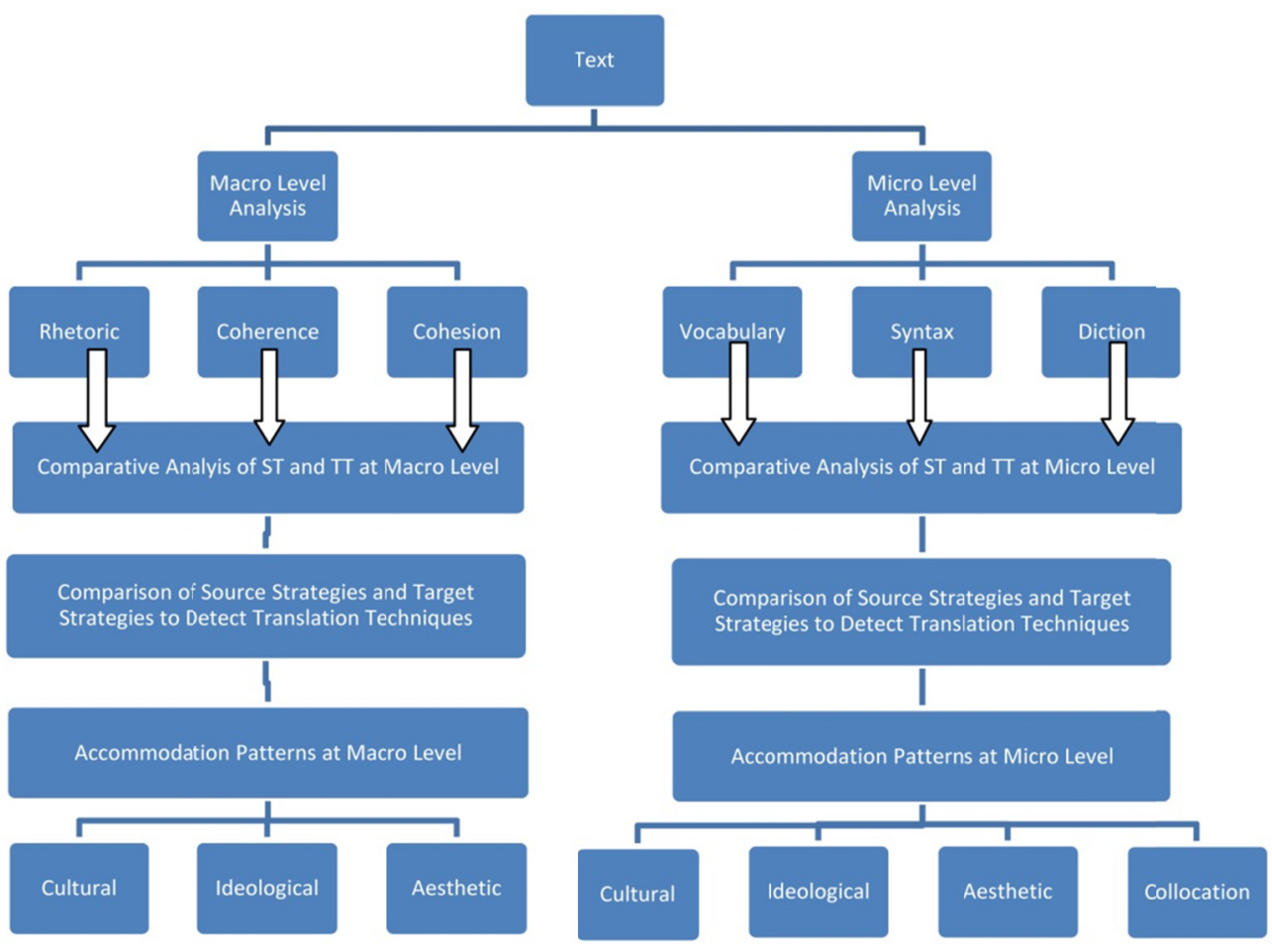

Figure 1. Model for comparative structures of source text and of the target text

\section{Data Analysis}

Presentation of data and then its analysis is considered a core of any study as being the most crucial stage of a research process. It is a place of collision of the whole study where the relevant and irrelevant elements are filtered in and filtered out respectively during the analysis of the collected data. In this study, nature of the data did not demand any statistical formula for the analysis of the data presentation of findings but for the purpose of imparting clarity and simplicity I have drawn help from graphs and tables. The analysis of the data is meant to find answer the primary research question of the present study. The main research question of the study is 'How has the translator of 'Overcoat' accommodated according to the socio-cultural and ideological context of Pakistan? According to the scheme of this study, data has been analyzed at both micro and macro level. Data from both source text and target text has been comparatively presented in tables.

\subsection{Analysis of Translation Strategies at Macro Level}

Table 1. Translation techniques at macro level

\begin{tabular}{|c|c|c|c|c|}
\hline $\begin{array}{l}\text { Sr. } \\
\text { No }\end{array}$ & Source Text & Target Text & Translation Technique & $\begin{array}{l}\text { Type of } \\
\text { Accommodation }\end{array}$ \\
\hline 1 & وه اينى تراش خر اش سح كافى فيشن ايبل معلوم هوتا & .................. & Omission & Aesthetic \\
\hline 2 & 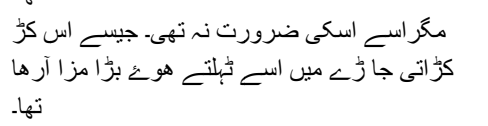 & $\begin{array}{l}\text { He was ambling along, } \\
\text { obviously enjoying his } \\
\text { promenade in the bitter cold. }\end{array}$ & Trans-editing & Aesthetic \\
\hline 3 & 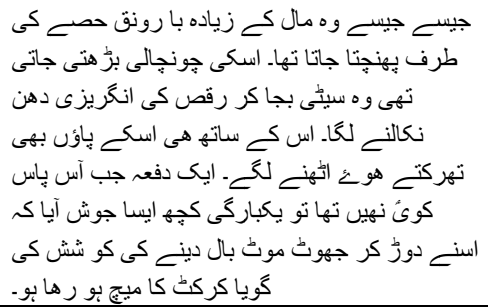 & 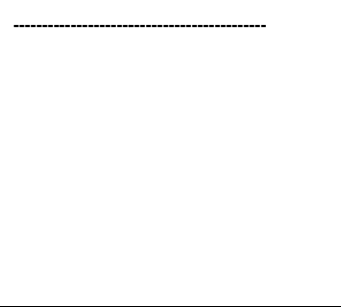 & Omission & Ideological \\
\hline
\end{tabular}




\begin{tabular}{|c|c|c|c|c|}
\hline 4 & 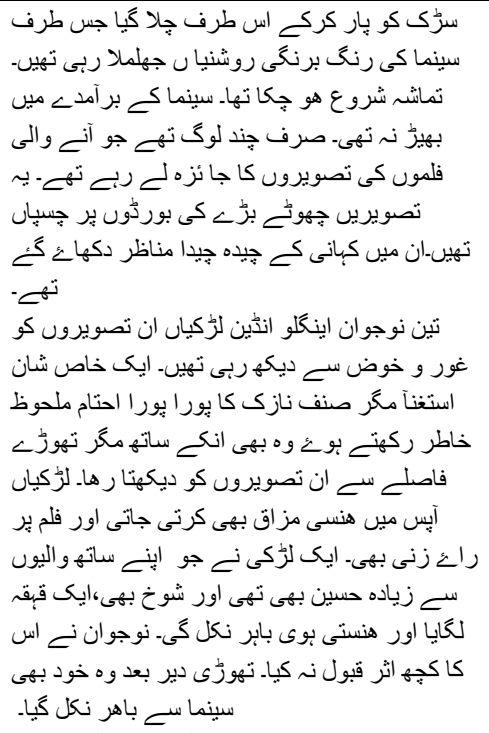 & & Omission & Ideological \\
\hline 5 & 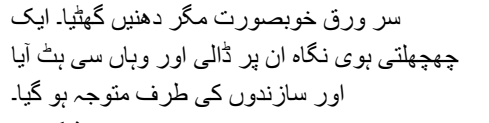 & & Omission & Ideological \\
\hline 6 & نبيس شكريـ-. & $\begin{array}{l}\text { No thanks, the young man } \\
\text { said with an air of } \\
\text { indifference as if } \\
\text { remembering something. }\end{array}$ & Addition & Aesthetic \\
\hline 7 & شكريـ ليكن اس وقت تو مين صرف د يكهن آيا & $\begin{array}{l}\text { Thank you so much, the } \\
\text { young man said approvingly. } \\
\text { A fine carpet indeed, I'll } \\
\text { come again sometime and he } \\
\text { walked away. }\end{array}$ & Trans-editing/Addition & Aesthetic \\
\hline 8 & ايكى خالى ثيكسى بهى اسه ديكه كر ركى. & $\begin{array}{l}\text { A taxi also drew near him } \\
\text { and the driver looked at him } \\
\text { enquiringly. }\end{array}$ & Explicitation & Aesthetic \\
\hline 9 & اسكى ي شد ت نا خوشكو ار نـ تهى بلكى لذت برستى دهى دهى & $\begin{array}{l}\text { It was cold that induced } \\
\text { people to seek comforts in } \\
\text { pleasure. }\end{array}$ & Trans-editing & Aesthetic \\
\hline 10 & 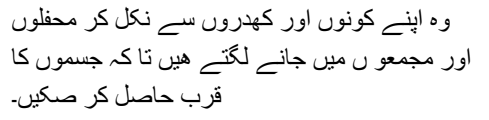 & $\begin{array}{l}\text { Who....... emerged from } \\
\text { their hideouts to join the } \\
\text { gaiety of the streets. }\end{array}$ & Trans-editing & Ideological \\
\hline 11 & 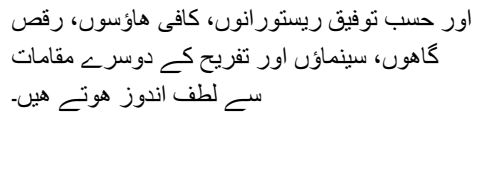 & $\begin{array}{l}\text { They amused themselves } \\
\text { among variety of hotels, } \\
\text { restaurants, cafes and snack } \\
\text { bars, each according to his } \\
\text { means }\end{array}$ & Omission & Ideological \\
\hline 12 & 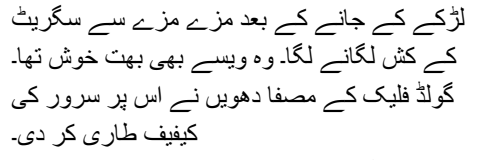 & $\begin{array}{l}\text { As he smoked he seemed to } \\
\text { relish ever puff. }\end{array}$ & Implicitation & Ideological \\
\hline 13 & ابك لمبى مبز بر مغربى موسيقى كى دو ورقى تهي & $\begin{array}{l}\text { On a long table attractively } \\
\text { displayed were the latest hit } \\
\text { songs. }\end{array}$ & Expanding & Aesthetic \\
\hline 14 & قا لينون كى ايك دوكان نـ اسكـ توجم كو جذ بـ & $\begin{array}{l}\text { A large Persian carpet which } \\
\text { was hanging outside a shop } \\
\text { attracted his attention. }\end{array}$ & Trans-editing & Aesthetic \\
\hline 15 & 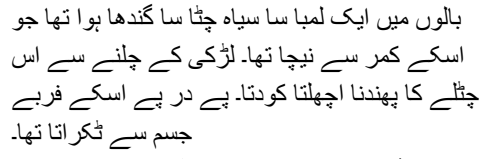 & (-) & Omission & Ideological \\
\hline 16 & 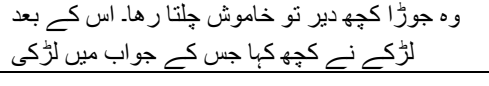 & 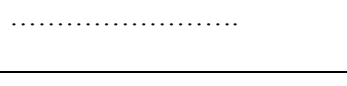 & Omission & Ideological \\
\hline
\end{tabular}




\begin{tabular}{|c|c|c|c|c|}
\hline & 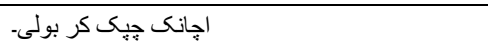 & & & \\
\hline & سنو مير ا كهنا مانو' لرغٔحه نـ نصيحت كـ انداز & & & \\
\hline & مين كها. داكثر مير ا دوست بح كسى كو كانو كان & & & \\
\hline & 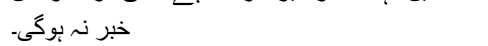 & & & \\
\hline & نبيب، نبيي، نهبي & & & \\
\hline & مين كيتا بوب تميس ذرا بهى تكليف نـ بو گى. & & & \\
\hline & لزُكى نــ كجه جو اب ديا' & & & \\
\hline & 'تمهار > باب كو كتنا رنج بو كا. ذرا انكى عزت كا & & & \\
\hline & 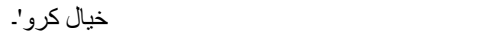 & & & \\
\hline & 'جِّ ربو ورنه مين پِاكل بو جاؤنكىى' & & & \\
\hline 17 & 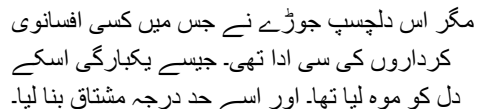 & 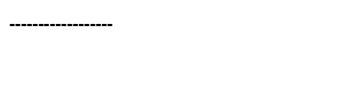 & Omission & Ideological \\
\hline 18 & 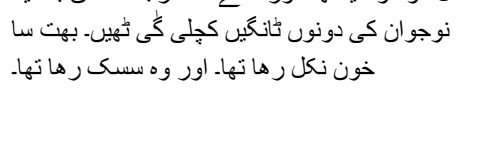 & $\begin{array}{l}\text { The young man was badly } \\
\text { hurt. There was a lot of blood } \\
\text { about and he was in a very } \\
\text { precarious state. }\end{array}$ & Trans-editing & Aesthetic \\
\hline 19 & 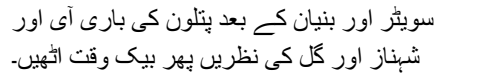 & $\ldots \ldots \ldots \ldots \ldots \ldots \ldots$ & Omission & Ideological \\
\hline 20 & 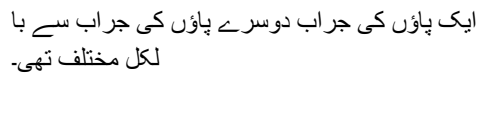 & $\begin{array}{l}\text { As to the socks, in colour and } \\
\text { pattern, one was quite } \\
\text { different from the other. }\end{array}$ & Explicitation & Aesthetic \\
\hline 21 & بلا شبـ اس وقت دم توزٌ جكا تهاء اسكا جهر ا جو & (................... & Omission & Ideological \\
\hline & 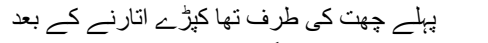 & & & \\
\hline & ديو ار كى طرف مزٌ كيا. معلوم بوتا تها كـ جسم اور & & & \\
\hline & روح كى برينكى نـ اسبح خجل كر ديا. اور وه اينه & & & \\
\hline
\end{tabular}

At macro level, the translator of 'Overcoat' accommodated 21 times out of which $11(52.38 \%)$ are caused by ideological factors whereas 10 times $(47.62 \%)$ are the results of the linguistic factors. Of the eleven ideological accommodations at macro level, the translator has omitted the source text nine times $(81.81 \%)$ to adjust the target text in the target context. On the other hand in linguistic (aesthetic and collocation) accommodations the translator has omitted only twice out of ten times. It also shows that in order to accommodate ideologically, the translator uses the technique that is conflicting to the faithfulness in translation whereas in linguistic accommodations, the translator has used other techniques of translation.

\subsection{Analysis of Translation Strategies at Micro Level}

Table 2. Translation techniques at micro level

\begin{tabular}{|c|c|c|c|c|}
\hline $\begin{array}{l}\text { Sr. } \\
\text { No }\end{array}$ & Source Text & Target Text & Translation Technique & $\begin{array}{l}\text { Type of } \\
\text { Accommodation }\end{array}$ \\
\hline 1 & 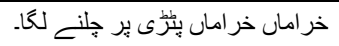 & Turned to the chairing cross & Explicitation & Aesthetic \\
\hline 2 & سرمه كى سلا ى' & Pencil & Synonym & Aesthetic \\
\hline \multirow[t]{2}{*}{3} & بيد كى جهزى & Polished cane & Addition & Aesthetic \\
\hline & 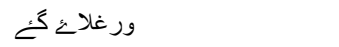 & induced & Synonym & Aesthetic \\
\hline 4 & تيز دهار كى طرح & Like steel & Synonym & Aesthetic \\
\hline 5 & وه اينه اينه كونوب--. & They.....their hideouts. & Transposition & Collocation \\
\hline 6 & 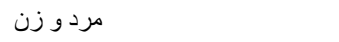 & People & Synonym & Aesthetic \\
\hline 7 & يان، بيرُى اور سكريط & Pan and cigarette & Omission & Aesthetic \\
\hline 8 & آو بهگت كىى & Greeted & & \\
\hline 9 & نوجوان كا إينا اور كوث & The overcoat, the young man was.. & Transposition & Collocation \\
\hline
\end{tabular}

At micro level it is evident that the translator has adjusted target text linguistically. There is no ideological adjustment at micro level.

\section{Findings of the Study}

The aim of this research was to investigate the linguistic strategies that a translator employ to adjust target text in 
new context. Analytical framework was devised with the fusion of Van Dijk (2005) model of language, ideology and context and Aiwe Shi (2004) model of accommodations in translation. Findings of the present research were analyzed qualitatively and quantitatively according to the parameters of the analytical framework selected for the study. Qualitative analysis helped in achieving the aim of arriving at a holistic picture and depth of the issues under discussion. Quantitative analysis helps to highlight the results in percentages by making comparisons.

The findings of this research specify that the text under analysis has evident traces of the patterns of accommodation adopted deliberately or as necessity by the translator of selected text. Moreover, the findings after comparative analysis of the source text and the target text designate that these adjustments have made the target text, an original one without giving any clues of distortion of message or overwriting.

These adjustments are necessary as they bridge the gap among the structures of the two languages and also among the ideological differences of the readers. That is why that the translator feels quite at home even in omitting the text while translation.

The findings of the present research also show that ideological accommodation is a common feature at macro level whereas linguistic accommodation occur both at micro and macro level.

The findings are not only valuable to translators and researchers working on translation from English into Urdu and vice versa, but these findings have some academic implications as well and accordingly have some value to language instructors and linguists involved in English-Urdu contrastive linguistics.

The findings of this study corroborate that the sentence structure, collocation patterns, improvisation of rhetorical tropes are also some important factors besides cultural and ideological factors that forced the translator to accommodate while translating.

\section{References}

Afzali, K. (2013). The translator's agency and the ideological manipulation in translation: The case of political texts in translation classrooms in Iran. International Journal of English Language \& Translation Studies.

Baker, M. (2006). Translation and Conflict: A Narrative Account. https://doi.org/10.4324/9780203099919

Creswell, J. W. (2007). Educational Research: Planning, Conducting, and Evaluating Quantitative and Qualitative Research (Vol. 136). University of Nebraska-Lincoln Boston.

Hatim, B., \& Mason, I. (1997). The Translator as Communicator. Language, 75(1), 182-183. https://doi.org/10.2307/417507

Ibraheem, A. K. (2013). Accommodation in Translation with Reference to English and Arabic. Al-Ma'mon College Journal, (21), 314-326.

Johnson, R. B., \& Onwuegbuzie, A. J. (2004). Mixed Methods Research: A Research Paradigm Whose Time Has Come. Educational Researcher, 1-14. https://doi.org/10.3102/0013189X033007014

Jost, J. T., Glaser, J., Kruglanski, A. W., \& Sulloway, F. J. (2003). Exceptions That Prove the Rule-Using a Theory of Motivated Social Cognition to Account for Ideological Incongruities and Political Anomalies: Reply to Greenberg and Jonas (2003). Psychological Bulletin, 129(3), 383-393. https://doi.org/10.1037/0033-2909.129.3.383

Lefevere, A. (1992). Translation-History-Culture. Routledge.

Munday, J. (n.d.). Introducing Translation Studies: Theories and Applications. Routledge.

Nord, C. (2001). Loyalty Revisited. The Translator, 7(2), 185-202. https://doi.org/10.1080/13556509.2001.10799100

Nord, C. (2006). Translating As a Purposeful Activity : a Prospective Approach. TEFLIN Journal, 17(2), 131143. Retrieved from http://www.revistas.usp.br/tradterm/article/view/49673/0

O'Halloran, K., Tan, S., Smith, B., \& Podlasov, A. (2010). Challenges in designing digital interfaces for the study of multimodal phenomena. Information Design Journal, 18(1), 2-21. https://doi.org/10.1075/idj.18.1.02hal

Schäffner, C. (2004). Political discourse analysis from the point of view of translation studies. Journal of Language and Politics, 3(1), 117-150. https://doi.org/10.1075/jlp.3.1.09sch

Sdobnikov, V. V. (2011). Translation Strategy Revised: the Communicative-Functional Approach. Journal of Siberian Federal University, 10(4), 1444-1453. 
Toury, G. (2000). The Nature and Role of Norms in Translation. The Translation Studies, 198-211.

Van Dijk, T. A. (2005). Politics, ideology, and discourse. Encyclopedia of Language and Linguistics, (1970), 728-740. https://doi.org/10.1016/B0-08-044854-2/00722-7

Yanow, D. (2004). Translating Local Knowledge at Organizational Peripheries. British Journal of Management, 15(S1), 9-25. https://doi.org/10.1111/j.1467-8551.2004.t01-1-00403.x

Zirker, A. (2016). Language Play in Translation: Character and Idiom in Shakespeare's The Merry Wives of Windsor. Crossing Languages to Play with Words: Multidisciplinary Perspectives, 3, 283.

\section{Copyrights}

Copyright for this article is retained by the author, with first publication rights granted to the journal.

This is an open-access article distributed under the terms and conditions of the Creative Commons Attribution license (http://creativecommons.org/licenses/by/4.0/). 